Supplement of Saf. Nucl. Waste Disposal, 1, 239-240, 2021

https://doi.org/10.5194/sand-1-239-2021-supplement

(c) Author(s) 2021. CC BY 4.0 License.

(c) (i)

Supplement of

\title{
The Grimsel Test Site - more than 35 years of underground research
}

Andrew J. Martin and Ingo Blechschmidt

Correspondence to: Andrew J. Martin (andrew.martin@ nagra.ch)

The copyright of individual parts of the supplement might differ from the article licence. 
Objective: Description of the future system - assessment of its performance

\section{Example:}

Complete HLW system

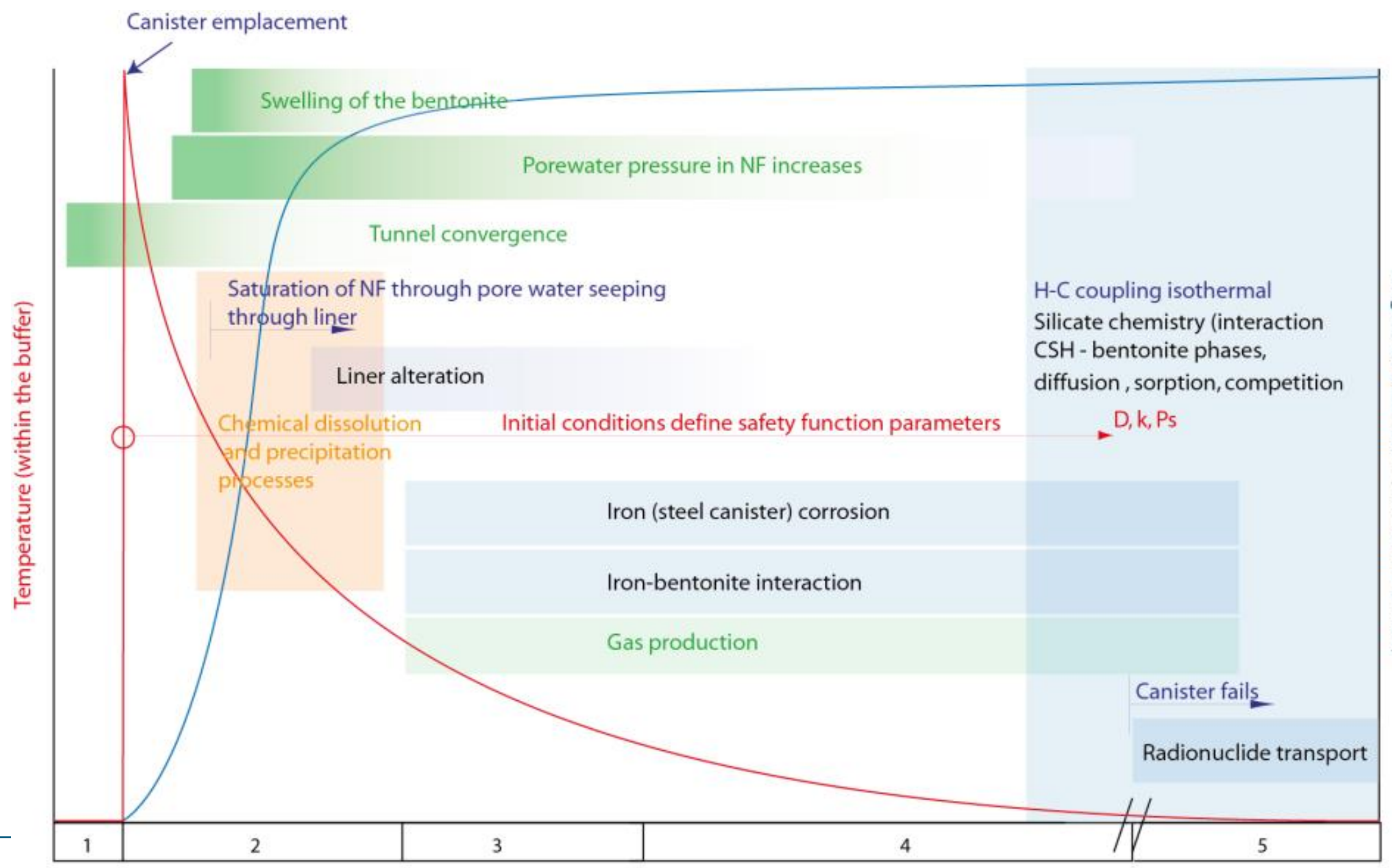




\section{Where/how do current URL activities contribute to the safety case}

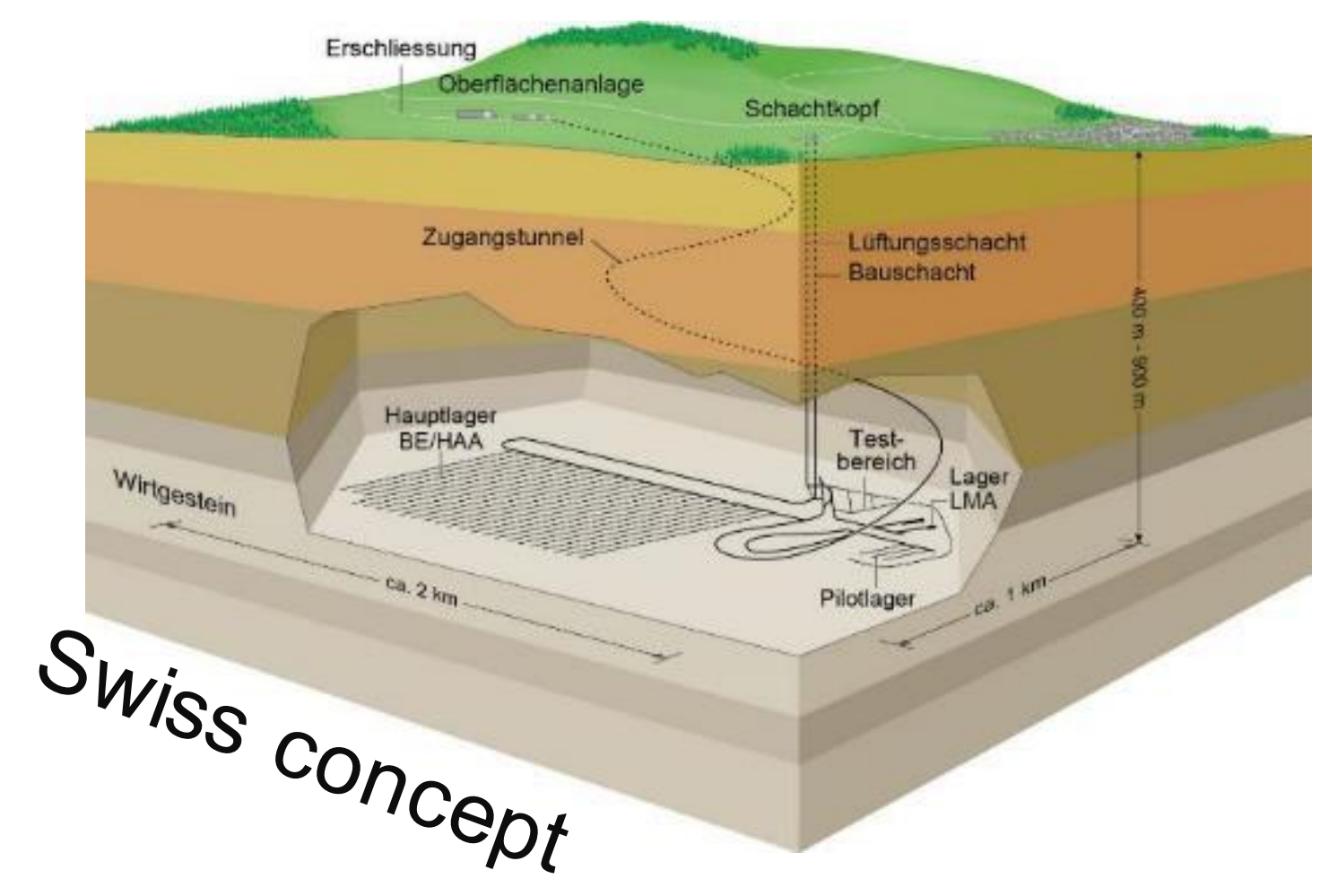

Diffusion and sorption In the clay

Rock mechanics

Self-sealing

Monitoring,

Performance confirmation

Thermal, chemical, biological processes

Spent fuel properties

Canister loading

Canister lifetime

Gas production
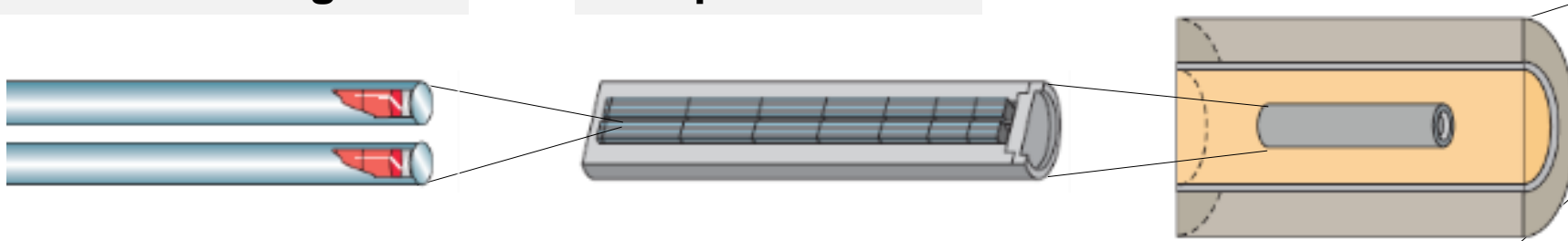

Engineered barriers 


\section{8 \\ Laboratory experiments}

Well defined boundary conditions, simulated environment

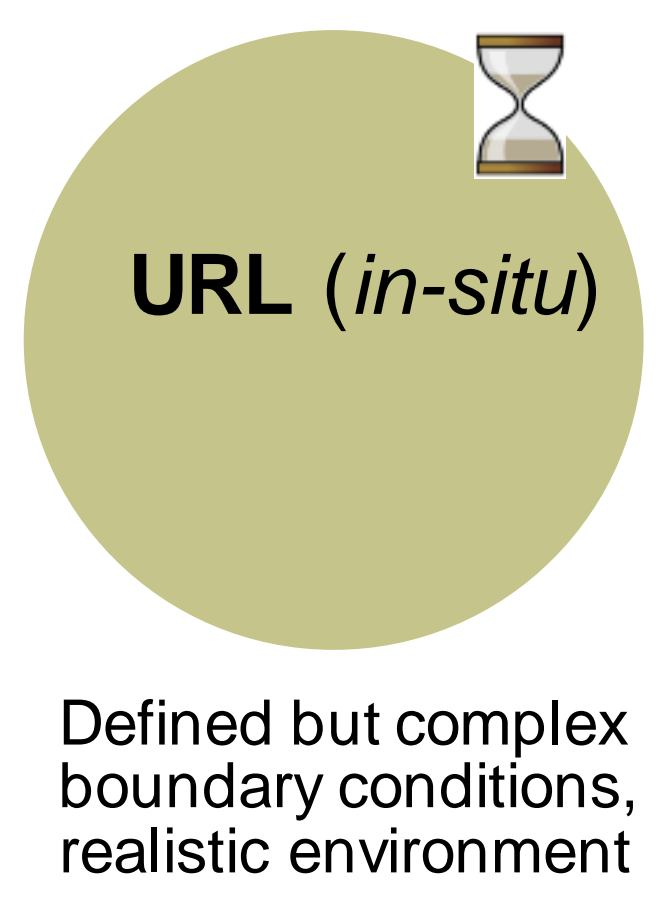

Dimension \& duration of the „experiments“, observation period

Weeks to

years

$\mathrm{mm} / \mathrm{cm}$
Several years

to decades

$\mathrm{cm} / \mathrm{m}$
Up to millions

of years

$100 \mathrm{~m} / 1 \mathrm{~km}$

Boundary conditions less well defined, realistic environment 


\section{Grimsel Test Site - an International Project}

$21+$ partner organisations from $12+$ countries \& EU

$\begin{array}{llll}\text { ANDRA } & \text { (France) } & \text { KIGAM } & \text { (Korea) } \\ \text { CRIEPI } & \text { (Japan) } & \text { KORAD } & \text { (Korea) } \\ \text { Ceramics } & \text { (Russia) } & \text { NAGRA } & \text { (Switzerland) } \\ \text { BASE } & \text { (Germany) } & \text { NUMO } & \text { (Japan) } \\ \text { BMWi/KIT(Germany) } & \text { NWMO } & \text { (Canada) } \\ \text { BGR } & \text { (Germany) } & \text { Obayashi } & \text { (Japan) } \\ \text { BGE } & \text { (Germany) } & \text { POSIVA } & \text { (Finland) } \\ \text { ENRESA } & \text { (Spain) } & \text { RWM } & \text { (United Kingdom) } \\ \text { ETHZ } & \text { (Switzerland) } & \text { SURAO } & \text { (Czech Republic) } \\ \text { HYRL } & \text { (Finland) } & \text { SKB } & \text { (Sweden) } \\ \text { JAEA } & \text { (Japan) } & \text { USDOE } & \text { (USA) } \\ \text { KAERI } & \text { (Korea) } & & \end{array}$

International Steering Committee Meeting - ISCO 2020
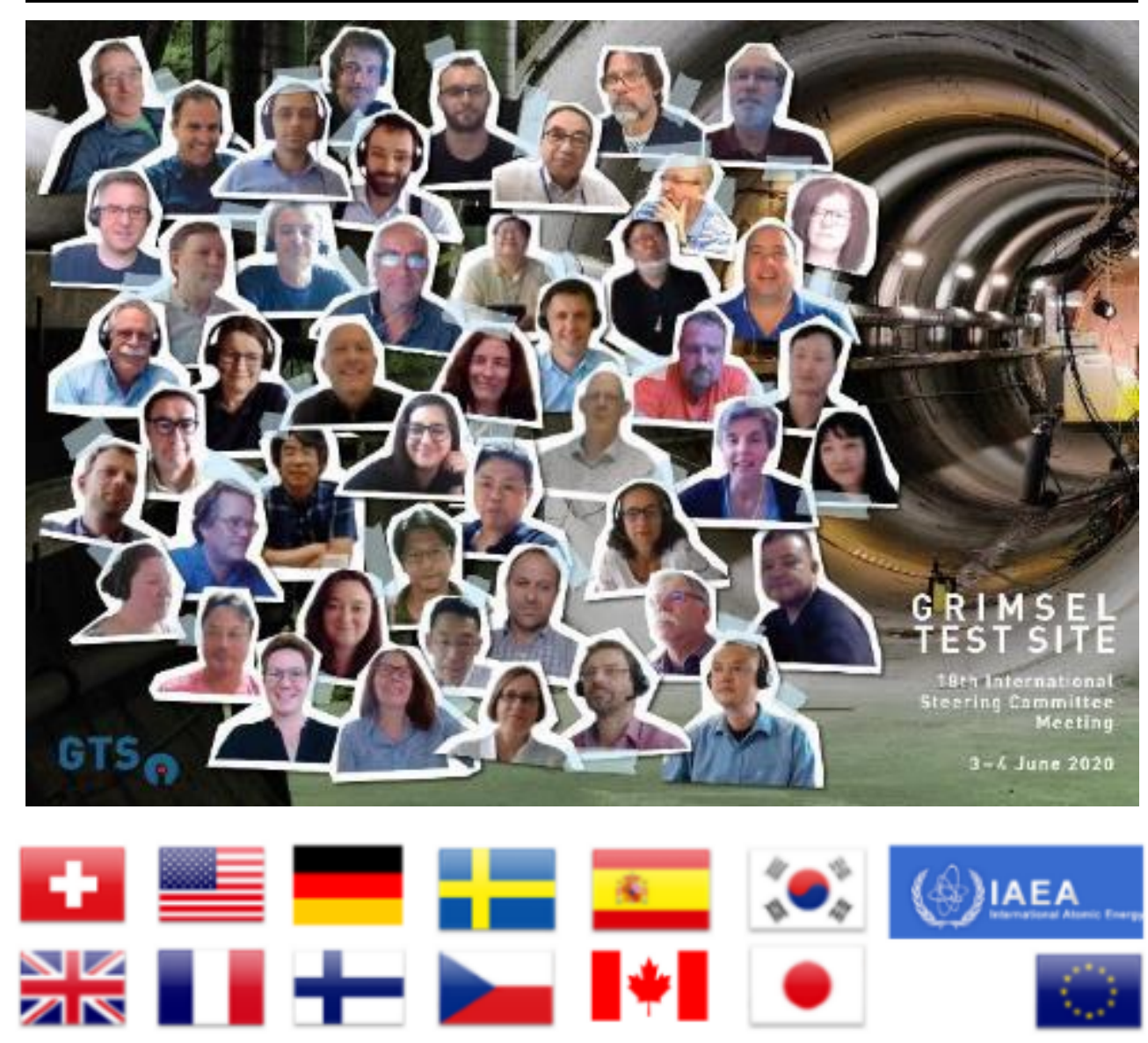

International collaboration in URFs is key for ensuring excellence, competence building, networking and optimal use of resources. 
GTS - Main Projects (Status November 2021)

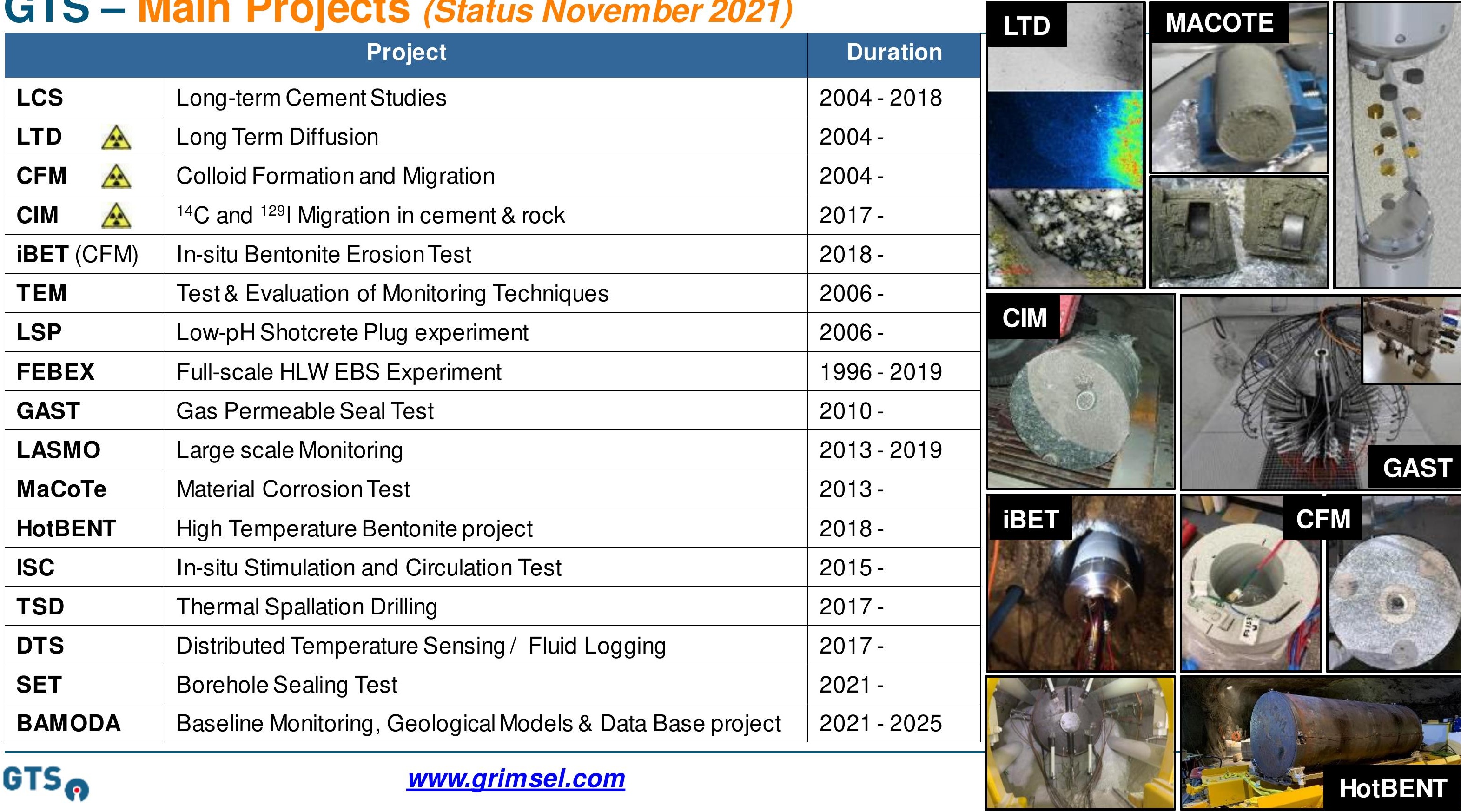




\section{The Long-Term Diffusion project (LTD)}

SURAO, NUMO, BASE, Nagra
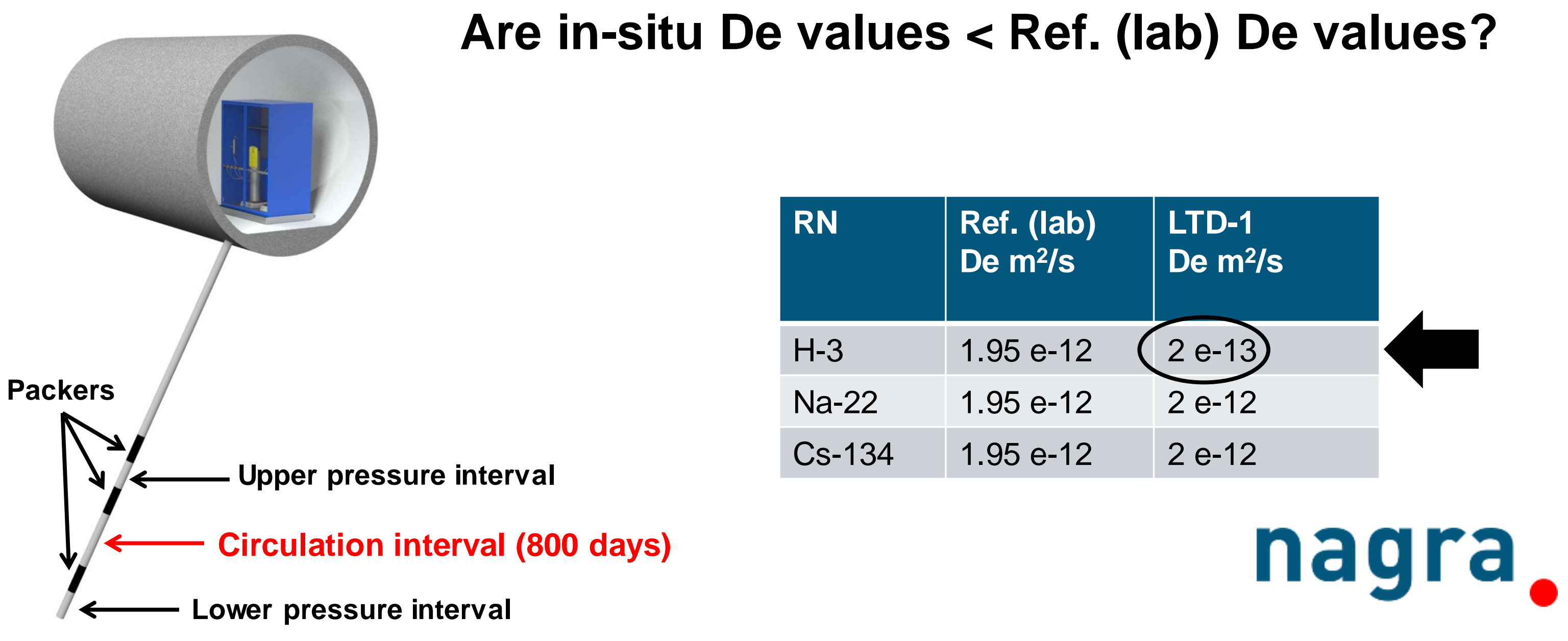
Second in-situ diffusion test in granite (1000 days)

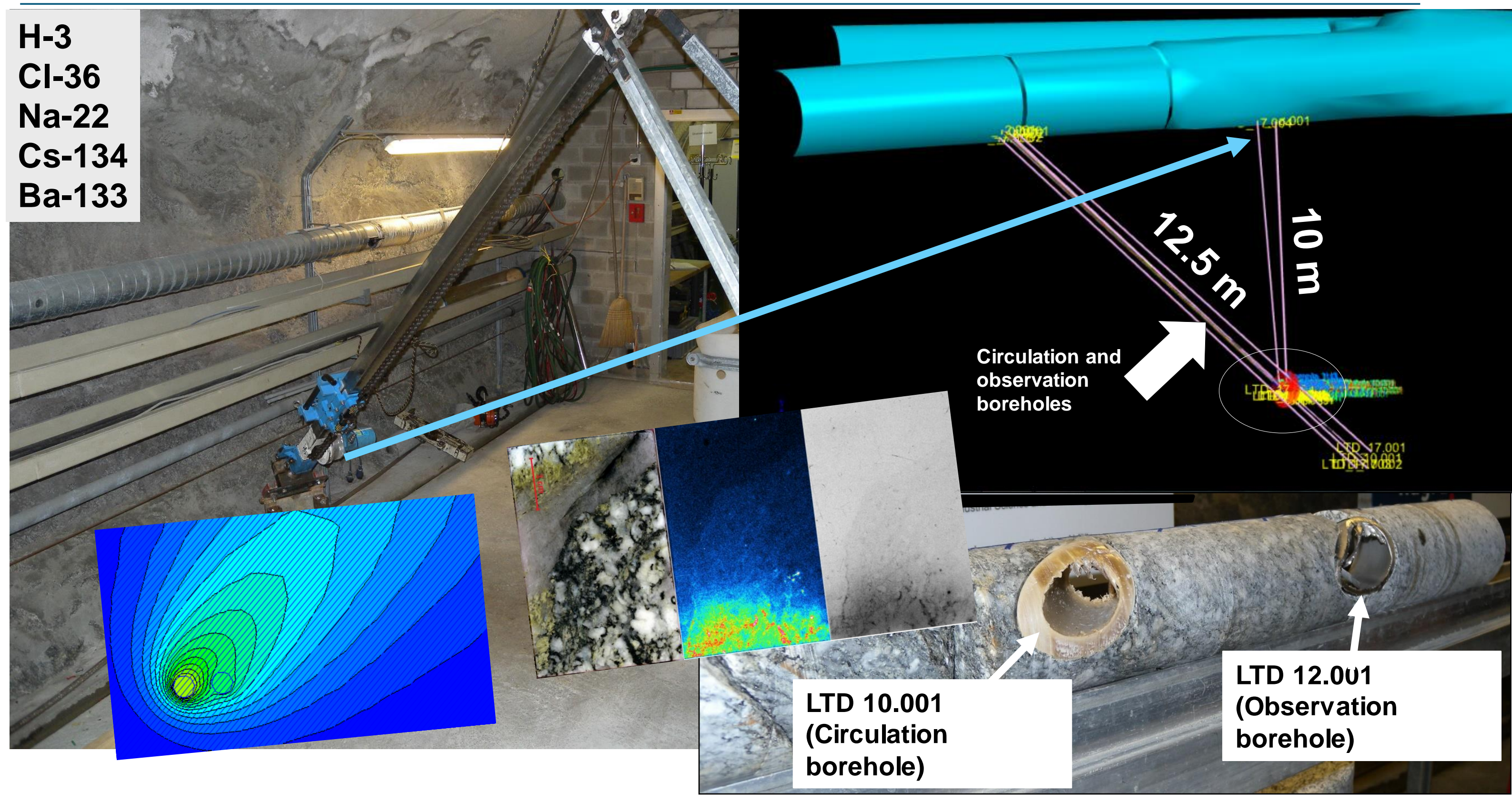




\section{CIM In-situ Migration of $\underline{\mathrm{C}}-14$ and $\underline{\mathrm{I}}-129$ in $\underline{\text { Cement }}$}

SURAO, RWM, NUMO, BASE, NAGRA
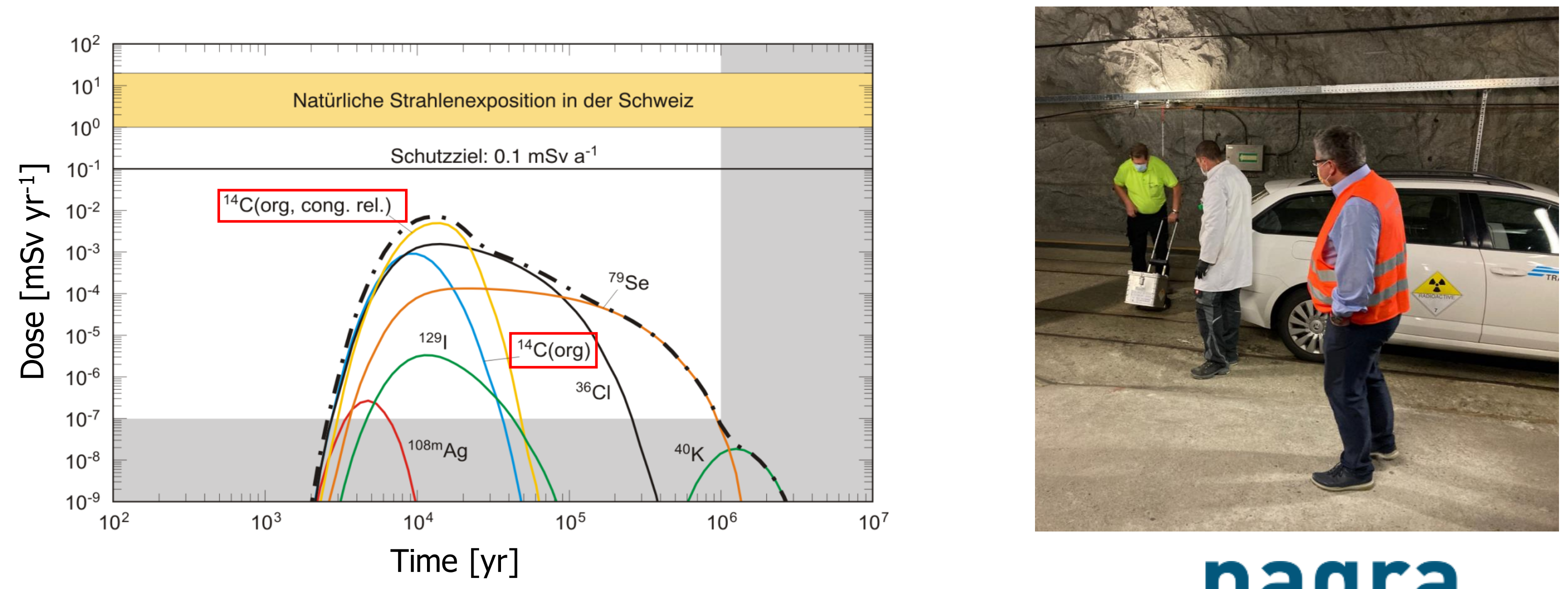

nagra. 


\section{Radionuclides circulating in $\mathbf{1 5}$ year old cement mortar in granite}

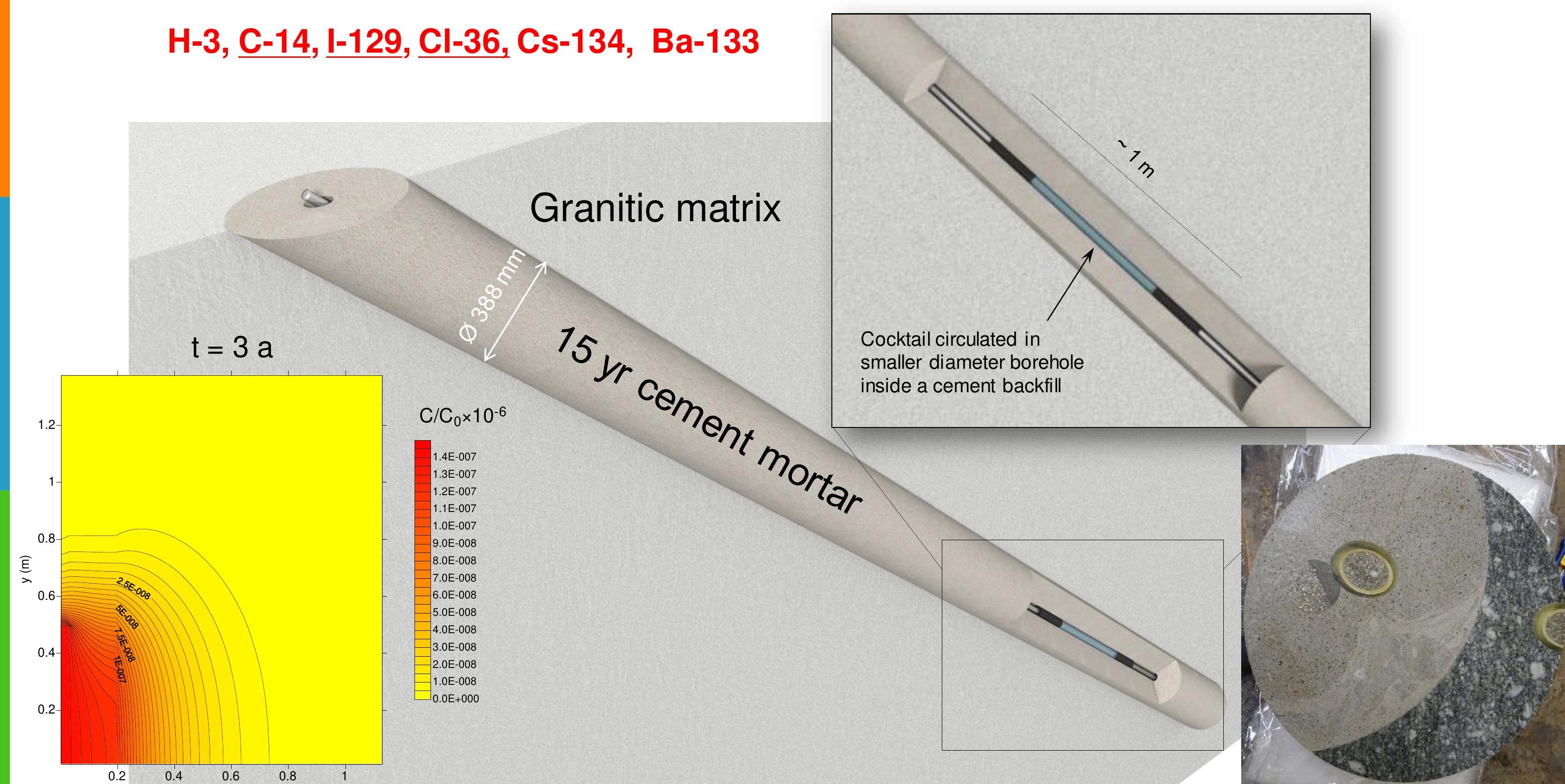




\section{MaCoTe (MAterials COrrosion TEst)}

NWMO, SURAO, RWM, NUMO, KIT, KIGAM, BASE, NAGRA
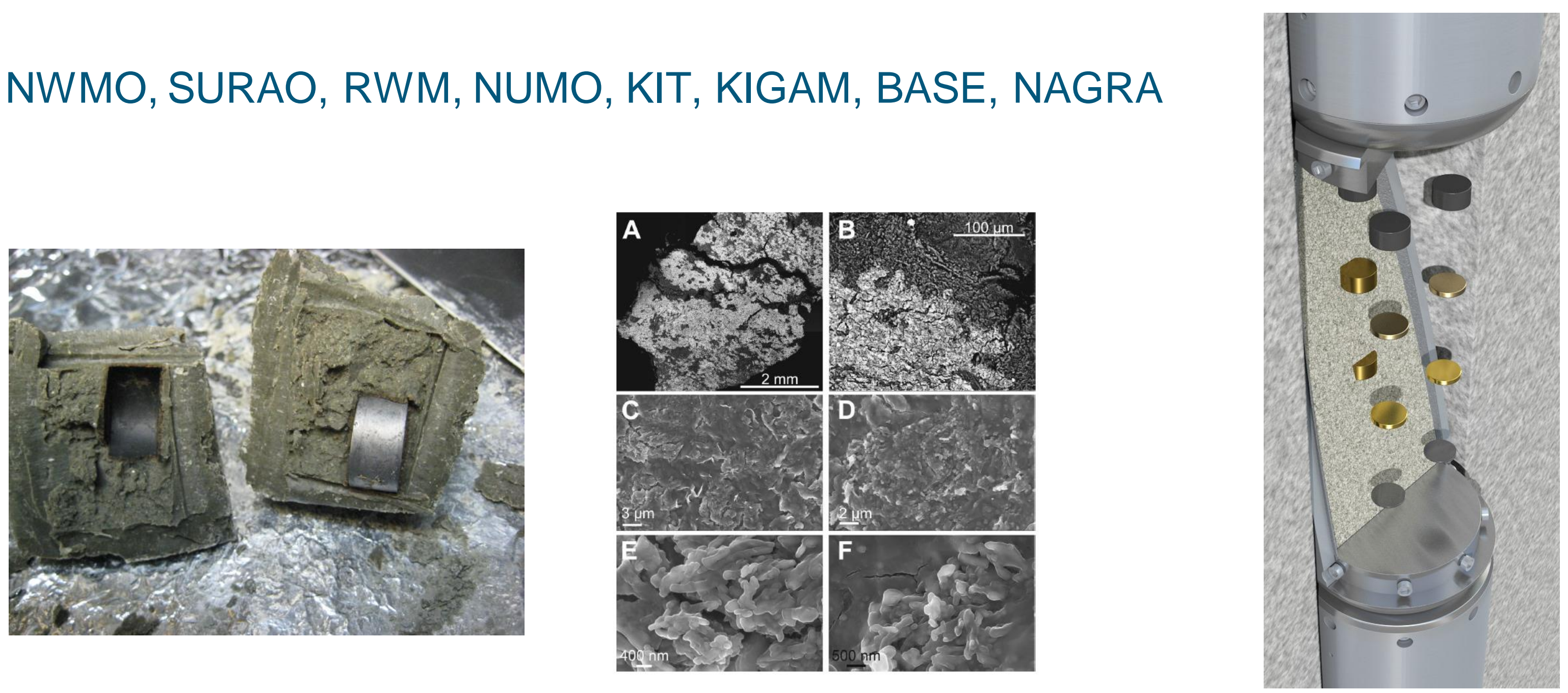

nagra. 


\section{Samples being tested}

- Carbon steel (forged + cast)

- Stainless steel

- Wrought copper

- Copper coatings (cold-spray and electro-deposited)

- Copper nickel alloy (used in evaporators/heat exchangers)

- Zirconium alloy (cladding of spent nuclear fuel) 


\section{Corrosion rates after 1 and 4.5 years of exposure}

\section{Weight loss}

Carbon steel
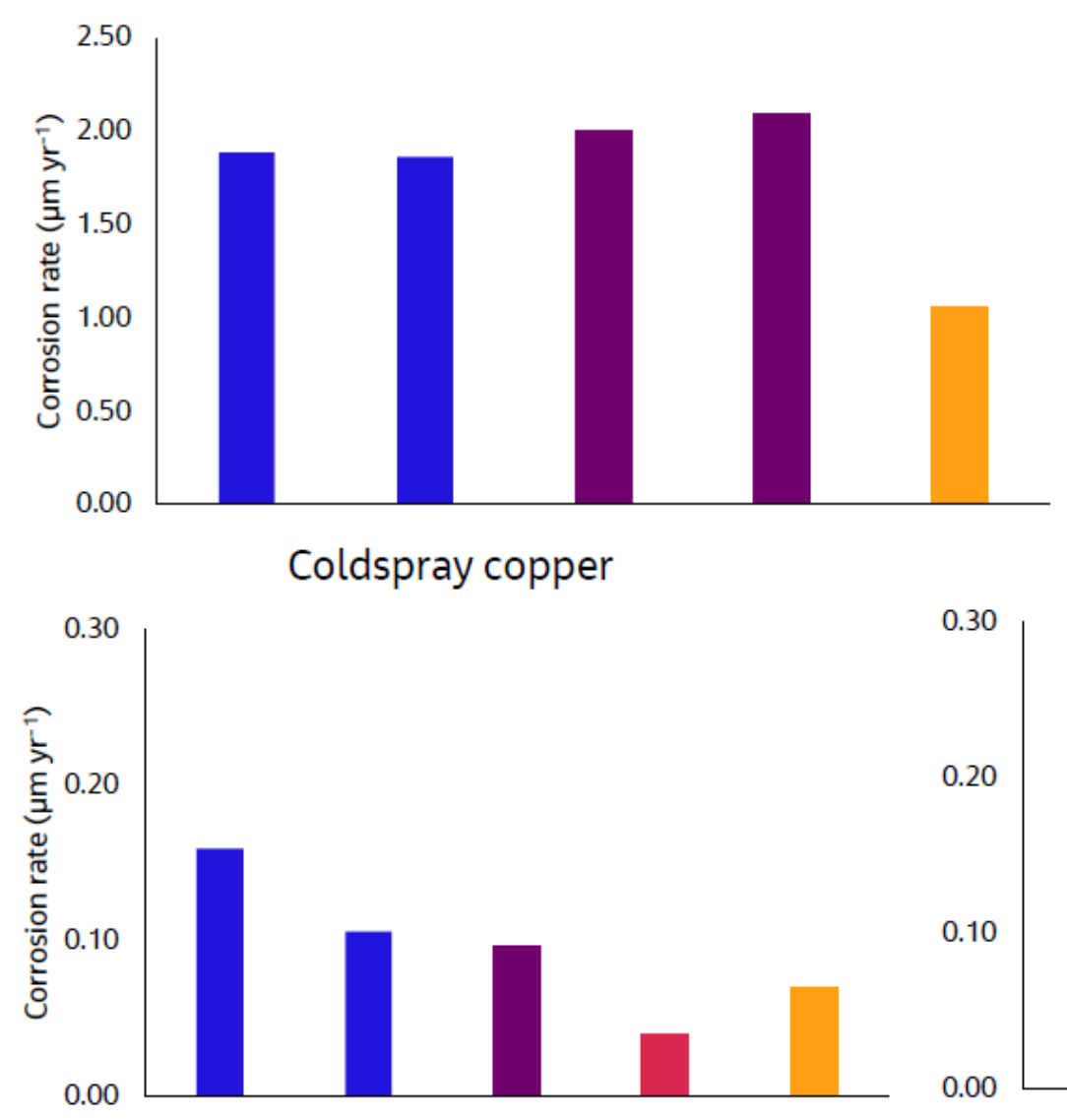

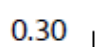

0.30
0.20

0.10

0.00
Electro-deposited copper

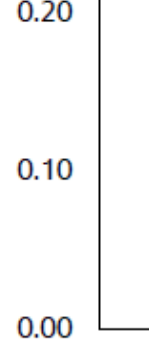

Module 1a (1.25 $\mathrm{Mg} \mathrm{m}^{-3}, 1$ year)

Module $2 \mathrm{a}\left(1.50 \mathrm{Mg} \mathrm{m}^{-3}, 1\right.$ year)

Module 3 (1.25 $\mathrm{Mg} \mathrm{m}^{-3}, 4.5$ years) - limited samples

Module 4 (1.50 $\mathrm{Mg} \mathrm{m}^{-3}, 4.5$ years) - limited samples 


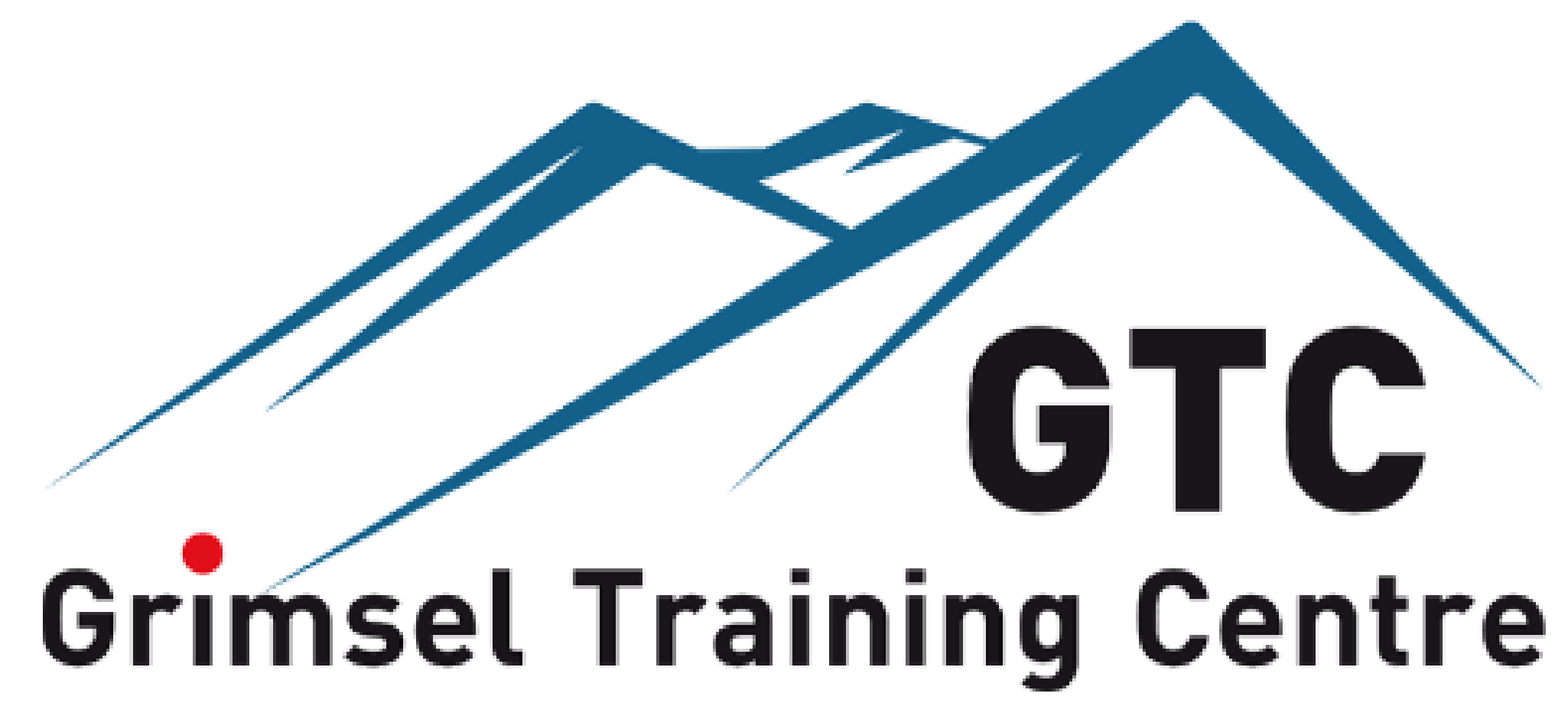




\section{Grimsel Training Centre (GTC)}

\section{Two courses successfully carried out in 2021:}

- Use of radioactive tracers in URL experiments (input to safety cases)

- Engineered Barrier System (EBS) Bentonite properties and applications

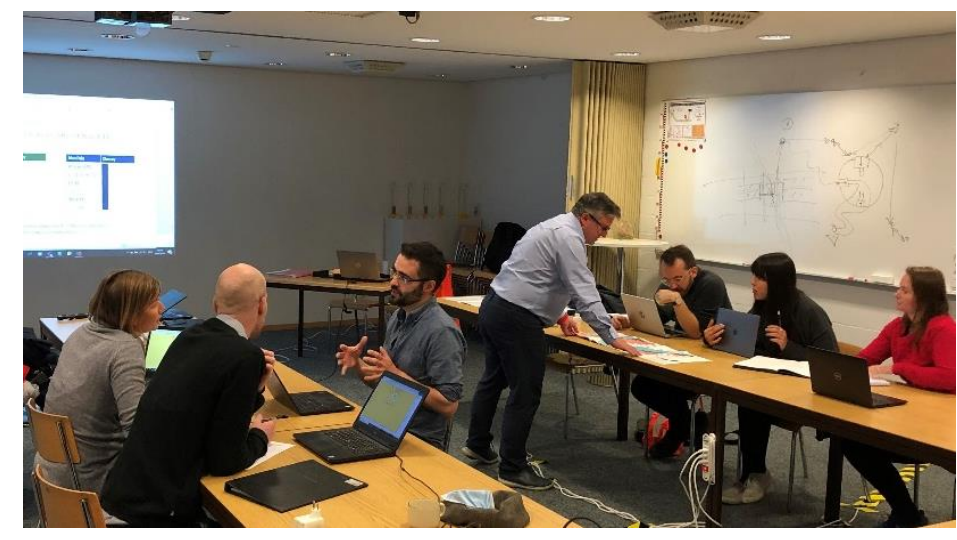

Feedback from the participants:

Covered topics, selection/experience and internationality of speakers was very much appreciated

$\checkmark$ The stay and availability of and the interaction with tutors beyond the lectures, during the lunch and dinner or even over several days was a highlight

Location, style, social programme and weather were just great
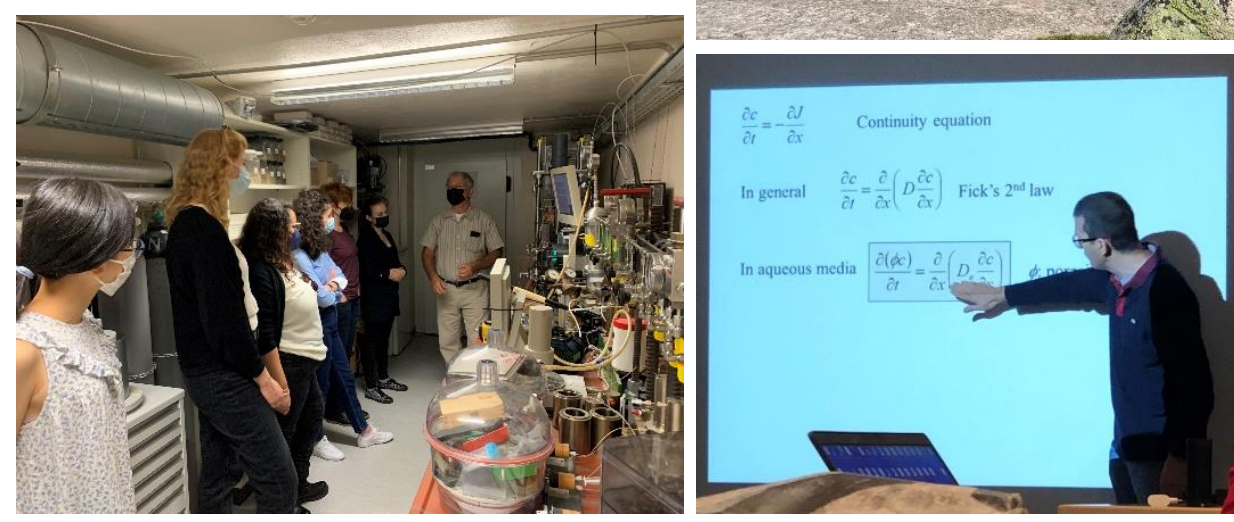


\section{Grimsel Training Centre (GTC): courses to come}

\section{GTC courses planned in 2022:}

- From RD\&D requirements to in-situ experiments - how to design and set up URL experiments

- Data management for geological and geophysical data: finding the needle in the haystack

- Site selection - an overview on possible approaches

...and tailor-made courses and workshops on request

\section{GTS}
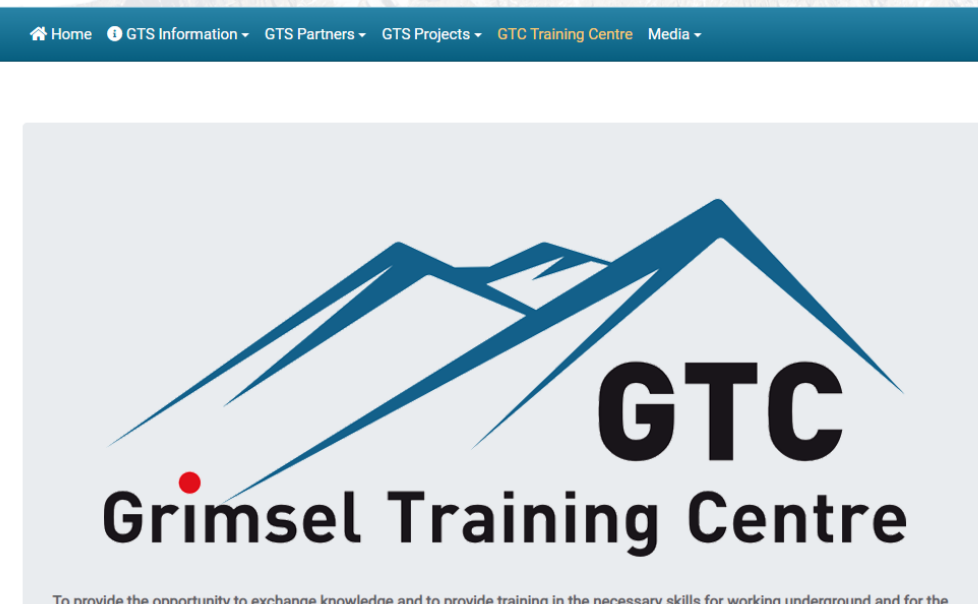

Upcoming courses on:

GTC Training Centre (grimsel.com) 


\section{Some concluding remarks}

- Work at the URLs is developed within the framework of the R\&D programmes and the disposal programmes, taking into account the safetyrelated requirements of the partner organisations involved

- International collaboration in the URLs is key to ensuring excellence, competence building, networking and optimal use of resources

- At the GTS, Nagra supports experiments that focus primarily on engineered barriers

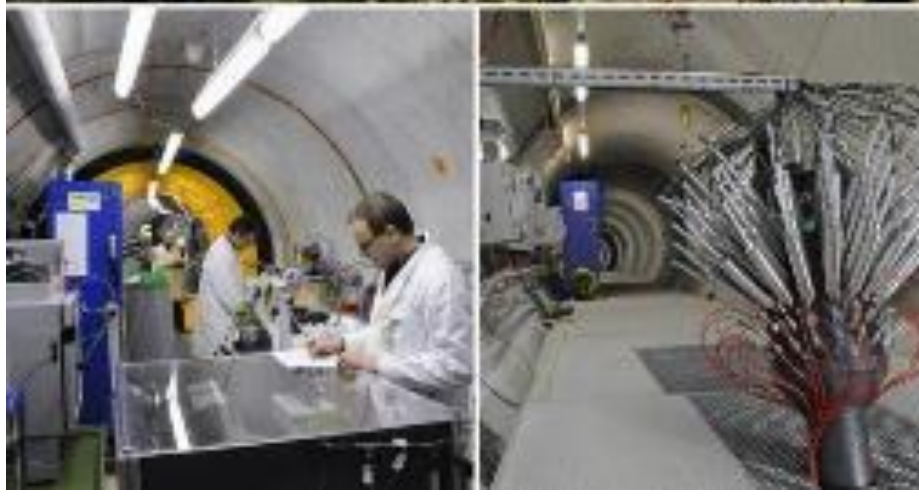

- Large-scale and full-scale long-term projects have been initiated to demonstrate the transient behaviour of repository components with a very long planning horizon

- A special feature of the FLG is the Radiation Controlled Zone, which allows researchers to study transport and retardation of $\mathrm{RNs}$ under realistic conditions

- Increasing demand on training and knowledge transfer $\rightarrow$ Grimsel Training Centre 


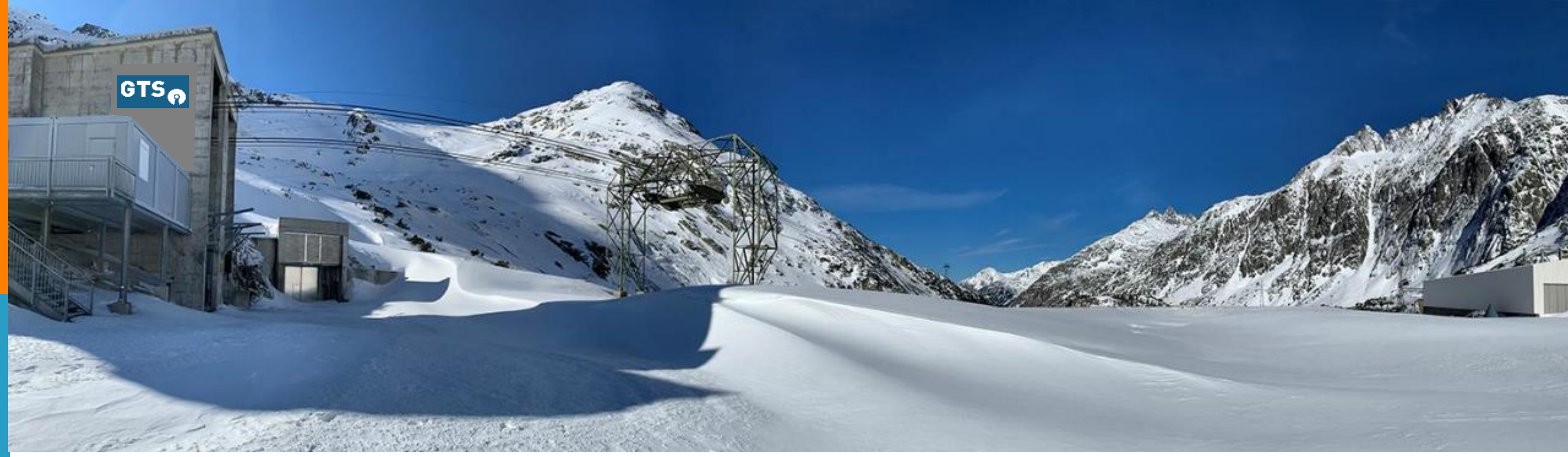

News \& Updates:

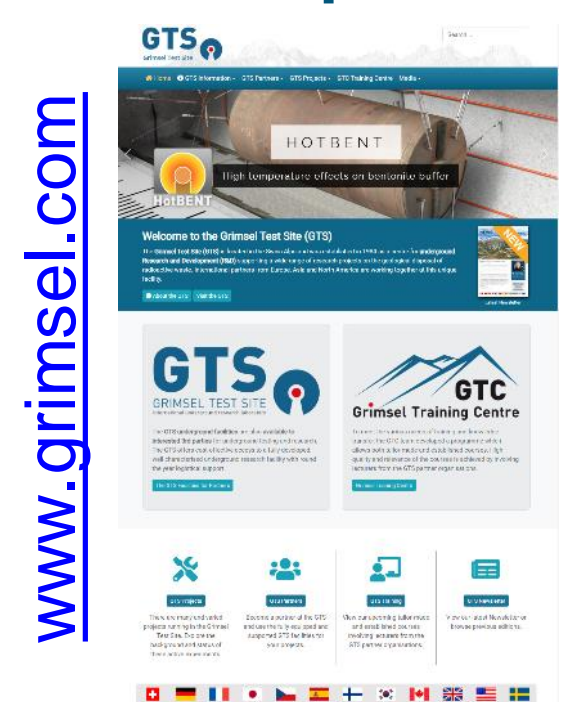

GTS NEWSLETTER: published twice a year

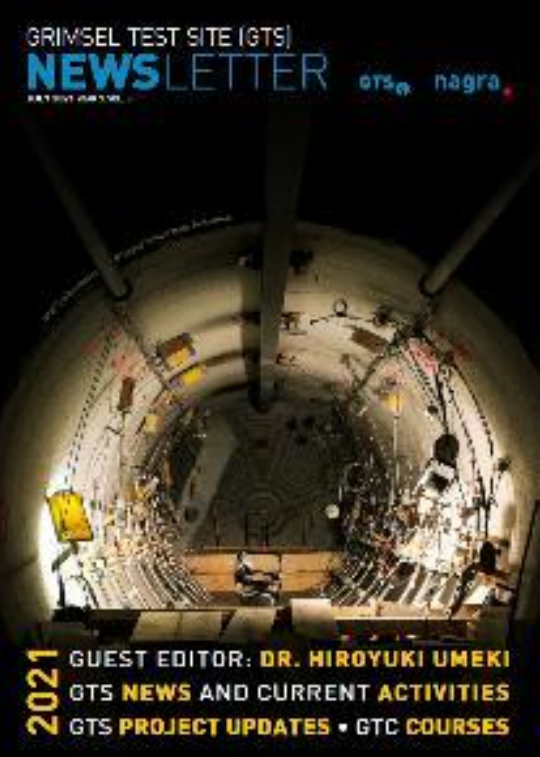

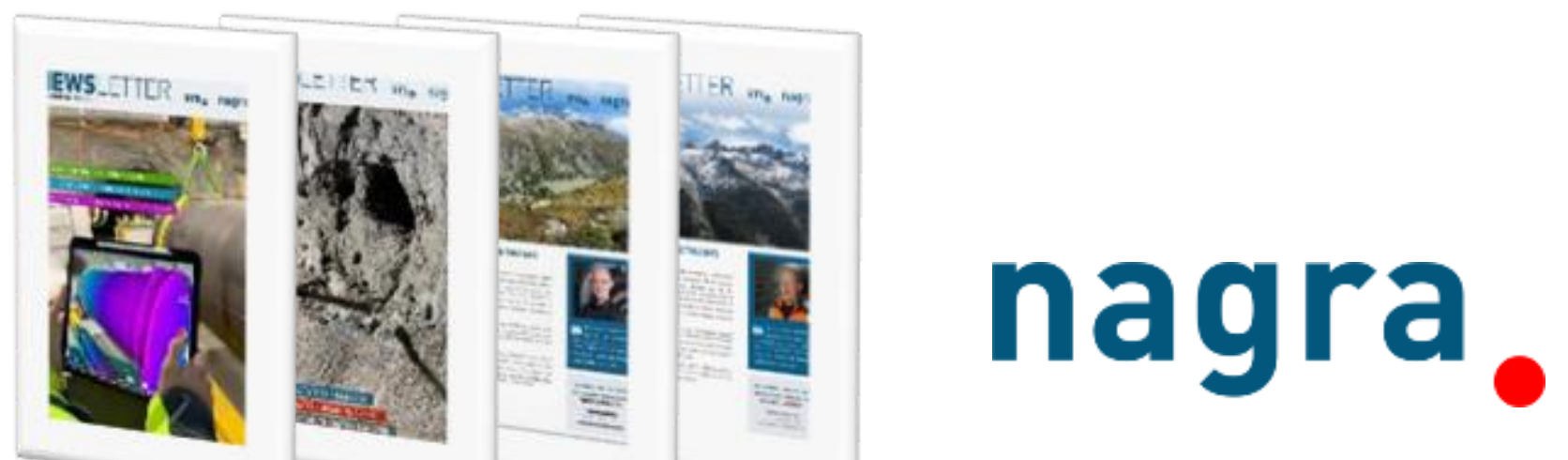

